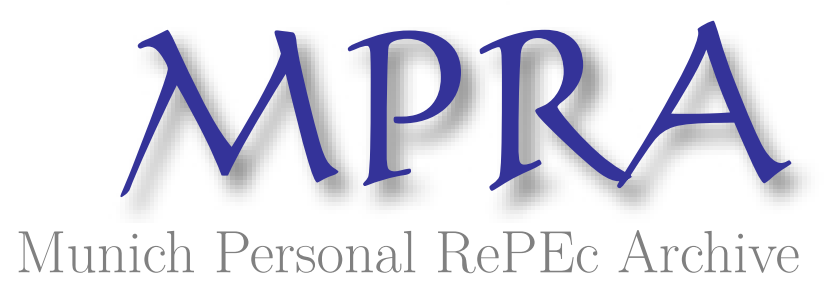

\title{
Harmonising Basel III and the Dodd Frank Act through greater collaboration between standard setters and national supervisors
}

\author{
Ojo, Marianne \\ University of Heidelberg
}

25 January 2012

Online at https://mpra.ub.uni-muenchen.de/36164/

MPRA Paper No. 36164, posted 25 Jan 2012 02:52 UTC 


\begin{abstract}
Having considered a vital means whereby the Basel III framework and the Dodd Frank Act could achieve a respectable degree of harmonization, in the paper which precedes this, namely, the paper on "Harmonising Basel III and the Dodd Frank Act through International Accounting Standards - Reasons why International Accounting Standards Should Serve as "Thermostats", this paper considers another important means of effectively achieving the aims and objectives of these important and major regulatory reforms aimed at achieving greater financial stability.

In so doing, it will highlight challenges encountered by the Basel III framework, as well as that encountered by the Dodd Frank Act - particularly in the areas of enforcement, coordination and communication. In facilitating better enforcement, the need for high level principles, bright line rules and a more effective mandate will be emphasized. Furthermore, a system whereby greater collaboration between standard setters and national supervisors can be better facilitated requires effective coordination and communication mechanisms aimed at ensuring that vital decisions and information are communicated timely, accurately, effectively and completely.
\end{abstract}

Keywords: financial stability, Volcker Rule, Basel III, Dodd Frank, European Systemic Risk Board, supervisors, Basel Committee, coordination, information asymmetry, regulation, high level principles 


\title{
Harmonising Basel III and the Dodd Frank Act Through Greater Collaboration Between Standard Setters and National Supervisors
}

\author{
Marianne Ojo ${ }^{1}$
}

\section{A. Introduction}

Basel III and Dodd Frank macro prudential measures aimed at facilitating financial stability will, to a significant extent, realize their desired results where consistently applied across respective and applicable jurisdictions. Furthermore, enhanced transparency in relation to vital issues which include Basel internal credit models will help facilitate market discipline. With regards to efforts aimed at harmonizing Basel and Dodd Frank requirements, national supervisors will play crucial roles in the translation of the Basel Committee's standards, as well as Dodd Frank requirements into national legislation.

Three important actors are involved in the link between macro prudential power players - namely; standard setters, central banks and national supervisors.

Micro prudential supervisors generally enforce rules whilst macro prudential coordinating bodies could establish rules which the micro prudential supervisor implements. ${ }^{2}$ As a result, there is need for clear unambiguous mandate and consistency in the application of standards, recommendations and regulations.

However, "even where another agency has the power to determine micro prudential instruments and even though macro prudential standard setters write laws which are being enforced by national supervisors, such supervisors still operate with autonomy and accountability". 3 Such need for autonomy and accountability, as well as ensuring consistent application of decisions regarding the composition of regulatory capital (as well as consistency in the application of other standards) across jurisdictions, also provides greater justification for "clear and unambiguous" mandate.

\footnotetext{
${ }^{1}$ Visiting Scholar, University of Heidelberg, Legal Scholarship Network Email : marianneojo@hotmail.com

${ }^{2}$ However, some micro prudential supervisors are endowed with the authority to issues rules and regulations. See Bank for International Settlements, "Central Bank Governance and Financial Stability" A Report by a Study Group May $2011<$ http:www.bis.org/publ/othp14.pdf> at page 56

${ }^{3}$ See ibid at page 60
} 
The stipulation of objectives in a "clear and explicit" manner, is considered to be "a powerful way of achieving clarity about the mandate. The articulation of a financial stability strategy within a clearly specified mandate being one such possibility of achieving clarity about the mandate - for example, by embedding the highest level objectives in statute, and then amplifying and interpreting the evolving understanding of what they imply for policy through high level strategy statements."

However, even though advantages exist in stipulating clear mandates, certain disadvantages also emanate from the stipulation of mandates in a "clear and explicit" way which does not provide for flexibility in relation to an area such as financial stability - an area which, to a large extent, involves contingency issues ${ }^{6}$ and uncertainty.

\section{B. Macro Prudential Oversight Frameworks}

The complementary and synergetic natures of functions relating to financial stability, as well as monetary policy setting functions, the need to couple such functions, is reflected by the following macro prudential oversight frameworks:

\footnotetext{
${ }^{4}$ Bank for International Settlements, "Central Bank Governance and Financial Stability” A Report by a Study Group May $2011<$ http:www.bis.org/publ/othp14.pdf> at page 30

${ }^{5}$ See ibid at pages 30 and 31; It is further added that such arrangements need to ensure the compatibility of financial stability operations with monetary policy responsibilities; see ibid

6 "Given the current state of knowledge about what constitutes financial stability, and its main drivers, attempting to direct policy actions by way of explicit objectives, may create practical difficulties. Three reasons being:

- It would be unfortunate if explicit objectives excluded policy options which turn out to be favorable

- A clear objective statement directing the policy to ensure financial stability, without indicating the limits to which the authorities are prepared to insure private agents against tail risk events, may induce greater risk taking than available policy instruments are able to cope with.

-The unpredictability of financial crises

For these reasons, it is important to have flexible legislation which is adaptable to potential changes" see ibid at page 30
} 


\begin{tabular}{|c|c|c|c|}
\hline & us & us: & EII \\
\hline Orersmaime thisty & $\begin{array}{l}\text { Pinumial Pobisy } \\
\text { Comsuines (FPC) }\end{array}$ & 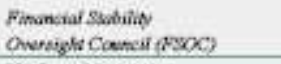 & 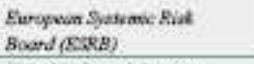 \\
\hline $\sin x$ & UKK Altuancial nystem & Us Ânancial vystem & EUladide dinancial arsoem \\
\hline Crerall utjeeren & 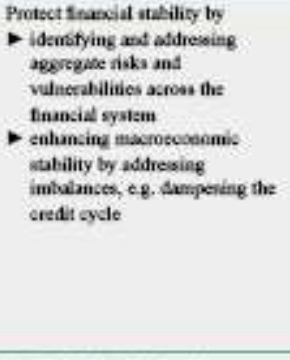 & 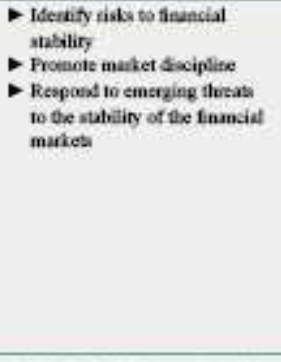 & 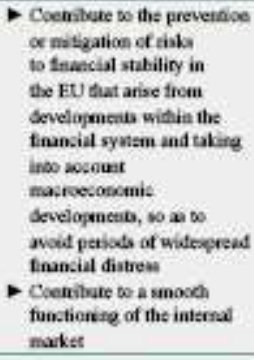 \\
\hline Rate or central lanas & 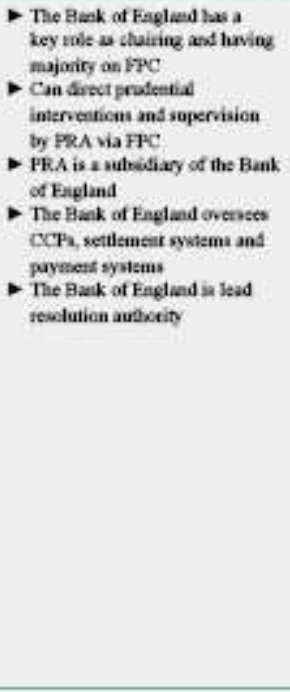 & 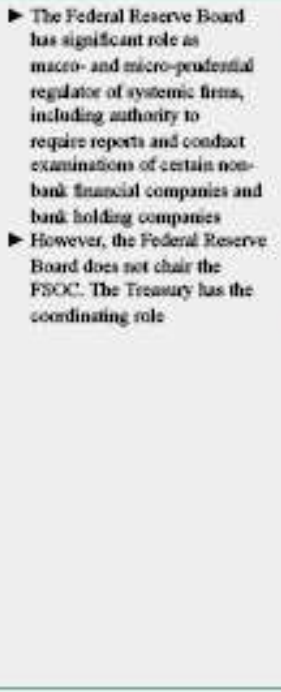 & 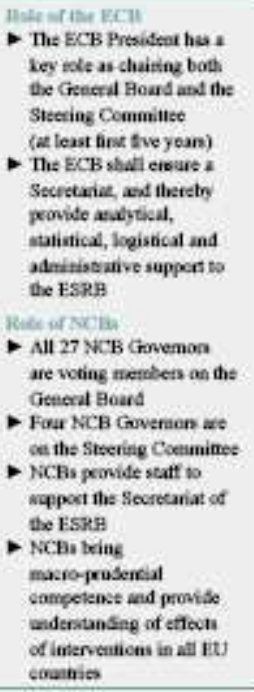 \\
\hline Criairmasagriseraf & 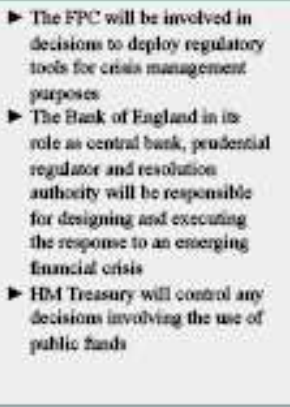 & 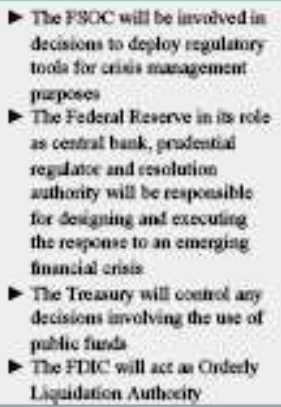 & 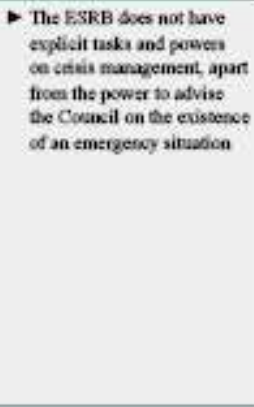 \\
\hline
\end{tabular}

Source: European Central Bank, Financial Stability Review

December 2010 at page 61 


\section{The European Systemic Risk Board (ESRB)}

\section{Establishment and Objectives}

Whilst the US Financial Stability Oversight Council was established by the US Dodd Frank Act, the European Systemic Risk Board (ESRB) was established on the basis of Article 95 of the EC Treaty as "a body without legal personality."7

The objective of the ESRB is considered to be three fold: ${ }^{8}$

- Developing a European macro prudential perspective to address the problem of fragmented individual risk analysis at national level

- Enhancing the effectiveness of early warning mechanisms by improving the interaction between micro and macro prudential analysis

- Allowing for risk assessments to be translated into action by the relevant authorities.

\section{The Need for Greater and More Commanding Mandate, High Level Principles and More Effective Enforcement.}

I. Non Binding Powers of the ESRB

Article 5 of the Regulations ${ }^{9}$ states that the ESRB "will not have any binding powers to impose measures on Member States or national authorities." Instead, Commission proposals describe the ESRB as a "reputational body with a high level composition that should influence the actions of policy makers and supervisors by means of its moral authority."

By virtue of Article 95 of the EC Treaty, mandate is also given to the ESRB to request for information from national supervisors where such information has not been provided.

\footnotetext{
7 "The legal basis on which the ESRB has been established endows it with a mandate which covers the entire financial sector without exceptions." See International Association of Risk and Compliance Professionals (IARCP), “The European Systemic Risk Board “ < http://european-systemic-risk-board.com $>$

8 See House of Commons Select Committees, “The Committee's Opinion on Proposals for European Financial Supervision" < http://www.publications.parliament.uk/pa/cm200910/cmselect/cmeuleg/5i/5i04.htm>

9 13648/09, Explanatory Memorandum and Commission Staff Working Document Accompanying Document to the Proposal for a Regulation of the European Parliament and of the Council on Community Macro Prudential Oversight of the Financial System and Establishing a European Systemic Risk Board.
} 
Owing to the non-legally binding effects of the ESRB's recommendations, its authority (or the ability of other authorities to comply with its instructions or mandate) may be questioned. However, its recommendations cannot simply be ignored. Addressees of recommendations must state whether they agree with its recommendations or not."

- The inability of the ESRB to issue binding recommendations has led some to describe it as a "toothless talking shop" which will duplicate activities already undertaken by other national and international institutions. ${ }^{11}$

\section{Challenges Faced By the Volcker Rule}

In his testimony, ${ }^{12}$ Tarullo highlights the challenges encountered in the implementation of statutory provisions relating to the Volcker Rule ${ }^{13}$. Problems highlighted not only embrace the fact that "the statutory definition of a fund covered under the Volcker Rule is quite broad, but also the fact that the statute also quite broadly prohibits any banking entity that serves as the investment manager, adviser, or sponsor to a covered fund, or that organizes and offers a covered fund, from engaging in certain transactions with the fund, including lending to, or purchasing assets from, the fund." Further identified challenging tasks which are involved in the implementation of the statutory provisions relate to the distinction between prohibited proprietary trading activities and permissible

\footnotetext{
10 "Given its wide scope and the sensitivity of its missions, the ESRB is not to be conceived as a body with legal personality and binding powers but rather as a body drawing its legitimacy from its reputation for independent judgments, high quality analysis and sharpness in its conclusions." See International Association of Risk and Compliance Professionals (IARCP), "The European Systemic Risk Board " < http://european-systemic-riskboard.com>

${ }^{11}$ See House of Commons Select Committees, "The Committee's Opinion on Proposals for European Financial Supervision" $<$ http://www.publications.parliament.uk/pa/cm200910/cmselect/cmeuleg/5i/5i04.htm>

12 See D Tarullo, "The Volcker Rule" Testimony before the Subcommittee on Capital Markets and Government Sponsored Enterprises and the Subcommittee on Financial Institutions and Consumer Credit, Committee on Financial Services, U.S. House of Representatives, Washington, D.C. January 18, 2012 http://www.federalreserve.gov/newsevents/testimony/tarullo20120118a.htm

13 "The statutory provisions that make up the Volcker Rule generally prohibit banking entities from engaging in two types of activities: 1) proprietary trading and 2) acquiring an ownership interest in, sponsoring, or having certain relationships with a hedge fund or private equity fund (each a covered fund). These statutory provisions apply, in general, to insured depository institutions; companies that control an insured depository institution; and foreign banks with a branch, agency, or subsidiary bank in the United States, as well as to an affiliate of one of these entities. "See ibid
} 
market-making activities. This distinction, it is added "is important because of the key role that market makers play in facilitating liquid markets in securities, derivatives, and other assets. The distinction between prohibited proprietary trading and permissible market making can be difficult to draw, because these activities share several important characteristics."

In recommending means whereby greater demarcation between proprietary trading and permissible market could be achieved, two options are put forward:

A simpler option which embraces

- High-level principles for differentiating prohibited and permitted activities and then leaving it to the firms to self-report violations based on internal models or other devices, presumably with compliance and systems monitoring by regulatory agencies.

A second alternative which would be to:

- Establish definitive bright lines for determining whether an activity is permitted or prohibited. This approach, in his opinion, is considered to be very difficult in practice, based on the current information and data, because of the many asset classes, as well as business models, and transaction types covered by the statutory provisions.

As reiterated at the end of the introductory section, even though advantages exist in stipulating clear mandates, certain disadvantages also emanate from the stipulation of mandates in a "clear and explicit" way which does not provide for flexibility in relation to an area such as financial stability - an area which, to a large extent, involves

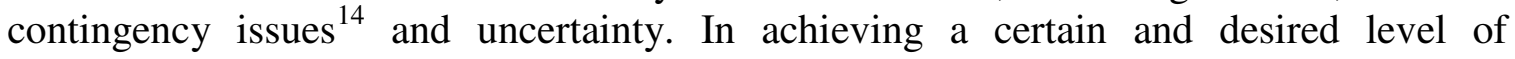

\footnotetext{
14 "Given the current state of knowledge about what constitutes financial stability, and its main drivers, attempting to direct policy actions by way of explicit objectives, may create practical difficulties. Three reasons being:

- It would be unfortunate if explicit objectives excluded policy options which turn out to be favorable

- A clear objective statement directing the policy to ensure financial stability, without indicating the limits to which the authorities are prepared to insure private agents against tail risk events, may induce greater risk taking than available policy instruments are able to cope with.

-The unpredictability of financial crises

For these reasons, it is important to have flexible legislation which is adaptable to potential changes" see ibid at page 30
} 
flexibility, a combination of bright line rules and high level principles is therefore recommended. ${ }^{15}$

\section{Conclusion}

Non binding powers of the European Systemic Risk Board (ESRB), as well as lack of effective enforcement mechanisms (in the form of adequate levels of bright line rules and high level principles) - as illustrated by the statutory provisions implementing the Volcker Rule have been identified in this paper as being areas in need of redress. The Basel Committee is also a body which is in need of greater authority and more binding powers which would also require the incorporation of high level principles and bright line rules. Just as more effective coordination and communication would be required between standard setters and supervisors such as the Basel Committee and national supervisors involved in the implementation of Basel III and the Dodd Frank Act regulatory reforms, clearer and more "authoritative" mandates are essential in ensuring that the goals of financial stability are achieved.

\footnotetext{
${ }^{15}$ For further information relating to the importance of a combination between bright line rules and high level principles and the need to attain the level of flexibility which derives from a combination of these, see M Ojo, "Building on the Trust of Management: Overcoming the Paradoxes of Principles Based Regulation" Banking and Financial Services Policy Report Volume 30 No 7 July 2011
} 


\section{REFERENCES}

Bank for International Settlements, "Central Bank Governance and Financial Stability" A Report by a Study Group May 2011 <http:www.bis.org/publ/othp14.pdf>

European Central Bank, Financial Stability Review December 2010

Explanatory Memorandum and Commission Staff Working Document Accompanying Document to the Proposal for a Regulation of the European Parliament and of the Council on Community Macro Prudential Oversight of the Financial System and Establishing a European Systemic Risk Board.

House of Commons Select Committees, "The Committee's Opinion on Proposals for European Financial Supervision" <

http://www.publications.parliament.uk/pa/cm200910/cmselect/cmeuleg/5-i/5i04.htm>

International Association of Risk and Compliance Professionals (IARCP), "The European Systemic Risk Board “ < http://european-systemic-risk-board.com>

Ojo M, "Building on the Trust of Management: Overcoming the Paradoxes of Principles Based Regulation" Banking and Financial Services Policy Report Volume 30 No 7 July 2011

Tarullo D, "The Volcker Rule" Testimony before the Subcommittee on Capital Markets and Government Sponsored Enterprises and the Subcommittee on Financial Institutions and Consumer Credit, Committee on Financial Services, U.S. House of Representatives, Washington, D.C. January 18, 2012

http://www.federalreserve.gov/newsevents/testimony/tarullo20120118a.htm 
